\title{
Te Ara Hou-A new pathway for leading Māori success as Māori
}

\section{Andrés P. Santamaría, Melinda Webber, Lorri J. Santamaría, Lincoln I. Dam, and Sharona Jayavant}

This article aims to document and evaluate the effectiveness of Te Ara Hou-The Māori Achievement Collaboratives (MACS). MACS is a nationwide grassroots educational leadership professional development project comprising 63 primary and intermediate school principals. These educational leaders meet at hui and wānanga several times a year to collectively engage with recent research and professional development to support their leadership practice toward achieving Māori success as Māori. In this article, MACS’ progress is measured against educational and leadership frameworks including Ka Hikitia and applied critical leadership. Complementary methodological frameworks employed are kaupapa Māori and critical race theory. Outcomes of this evaluation indicate that MACS is a culturally situated, culturally appropriate, and Māori-centric group of Māori and non-Māori principals committed to shifting their own leadership practice and school culture from what is to what can be. Findings suggest movement in the leaders' practice from responding to students' culture to making deliberate choices that result in actions and practices that positively impact upon and change school 
culture. There is evidence of school shifts to reflect a Māori worldview as the norm, rather than the exception, even in mainstream schools where there are relatively low numbers of Māori. MACS shows promise in terms of promoting practice that benefits Māori, all learners, schools, and their communities (e.g., whānau, hapū, iwi). Exemplars and implications are provided.

In 2013, a core group of six experienced primary school principals (four Māori and two non-Māori) formed Te Ara Hou-Māori Achievement Collaboratives (MACS), a school leadership initiative for mainstream primary and intermediate school principals, in partnership with the New Zealand Principals Federation (NZPF), Te Akatea Māori Principals Association, and, more recently, the New Zealand Ministry of Education. MACS is a grassroots leadership-based initiative committed to the goal of Māori educational success as Māori, as defined by Ka Hikitia-Accelerating Success 2013-2017 (Ministry of Education, 2013). MACS' vision of 'A Change in the Hearts and Minds of Principals' reflects an intention to foster personal and professional growth leading to changes in individual school leadership practices aimed at Māori success. The initiative's guiding principle is whānau and whanaungatanga, and its overarching values are courage, honesty, trust, respect, and commitment (Pearson et al., 2014). MACS principals engage in whanaungatanga to positively influence and impact their personal and professional learning in order to collectively identify, develop, and implement effective school leadership practices that promote and sustain positive Māori student achievement and success as Māori. The ultimate goal of the initiative is to establish a critical mass of effective school leaders and leadership practices which challenge status quo strategies that have resulted in inequitable educational outcomes for Māori. These inequitable 
outcomes are a result of educational challenges such as the: competitive nature of self-managing schools; absence of mātauranga Māori in the New Zealand curriculum; lack of cultural responsive pedagogy; deficit theorising of Māori students; and poor teacher-student and school-whānau/iwi/hapū relationships (Alton-Lee, 2003; Bishop, Berryman, Cavanagh, \& Teddy, 2009; Wylie, 2009).

MACS' theory of change has focused primarily on the school leader's role in initiating systemic change at the school level to counter historical systems of practice that intentionally or unintentionally result in educational disparities for Māori. MACS believe that effective school leaders must look to a future where their schools benefit from indigenous knowledge-forming and culturally sustaining pedagogies that value and integrate indigenous knowledge and worldviews. In doing so, MACS established the following set of goals for Māori and non-Māori mainstream school principals:

- to provide an education that enhances what it means to be Māori

- to ensure Māori students have access to te ao Māori-access to language, culture, marae, tikanga, and resources

- to guarantee the absolute right for an education that fits Māori learners

- to promote self-learning, strong secure relationships, cultural identity, and whānau-centred practice that is valued as much as academic achievement (Pearson et al., 2014).

Furthermore, it is a shared understanding among the MACS principals that they are operating according to the bicultural Treaty of Waitangi within mainstream schools, and that when schools address barriers to student achievement for Māori students, all students benefit, including Pasifika, students with special needs, and students from low socioeconomic backgrounds.

MACS comprises six regional clusters across Aotearoa-Te Tai 
Tokerau, Tāmaki Makaurau, Kirikiriroa, Rotorua, Taranaki, and Kahukura. Each cluster is made up of 10-12 Māori and non-Māori principals and facilitated by one of the original MACS core group members. To date, there are a total of 63 MACS principals, as follows. - School level $(n=63): 84$ percent primary (Years $0-6$ or ages $5-11$ ); 16 percent intermediate (Years $7-8$ or ages $12-13$ ).

- Decile level ( $n=63)$ : 41 percent low decile (deciles 1-3); 40 percent mid decile (Deciles 4-7); 19 percent high decile (deciles 8-10).

- Gender $(n=63): 57$ percent female; 43 percent male.

- Ethnicity $(n=45)$ : 40 percent Māori; 60 percent non-Māori.

Cluster facilitators organise "engine room" hui at least once per school term to connect inter-cluster experiences, identify areas of growth and need, and set agenda items for upcoming individual cluster hui. Regional cluster meetings focus on sharing data-driven innovative practices using disaggregated achievement data for Māori students to inform professional development (PD), pedagogy, and curriculum. Moreover, potential outcomes indicative of principals effectively engaged in and implementing the intended goals within their schools include, but are not limited to:

- establishing an inclusive school culture that values whanaungatanga, manaakitanga, mana motuhake and the importance of identity

- strengthening relationships between teachers, students, whānau, hapū and iwi

- advocating for student voice and agency

- promoting cultural competency across all members of school staff through professional learning

1 In New Zealand, a school's decile rating indicates the extent to which it draws its students from low socioeconomic communities. Schools in the lowest socio-economic communities are classified Decile 1, while Decile 10 schools are in the most privileged communities. 
- provision of te reo and tikanga Māori programmes for staff, students, and community

- embedding culturally and geographically specific histories within school curriculum

- demonstrating greater knowledge, understanding and inclusion of the principles of Te Tiriti o Waitangi

- sharing knowledge, expertise and resources across schools and actively engaging and supporting each other to achieve goals and targets

- seeking alternative professional development providers: i.e. iwi, hapū, Māori led, Māori knowledge and expertise

- developing student graduate profiles for mainstream and Māorimedium pathways

- aligning the school charter, strategic plan, annual targets and school budget to achieve these goals.

\section{The Cross-Cultural Research Collaborative}

In March 2014, the founding MACS principals invited a core team of three academic scholars, named in this study as the CrossCultural Research Collaborative (CCRC), to act as independent researchers to work alongside them in partnership using kaupapa Māori-centric action research to achieve their overarching goal of promoting positive Māori student outcomes (Baker, Pipi, \& Cassidy, 2015). Experiencing similar dynamics resulting from navigating the space between Māori and non-Māori worlds, this cross-cultural, interdisciplinary (e.g., educational leadership, educational psychology, multicultural multilingual education, special education, critical studies, indigenous education) and international team began with one Māori (Ngāti Whakaue, Ngāpuhi) researcher and two culturally and linguistically diverse (CLD) researchers (Mexican/Irish/ 
Italian-American and African-American/American Indian (Choctaw Nation Oklahoma)) from the U.S. Since the start of the partnership, CCRC has grown to also include two doctoral candidate research assistants (Thai/Cambodian/Chinese/Kiwi and East Indian immigrant) from Aotearoa New Zealand. CCRC is self-funded through research award grants it has won. This report reflects an evaluative inquiry conducted during 2014-2015 (CCRC), to measure the efficacy of the leadership actions of MACS principals in promoting Māori success in mainstream school settings.

Per the cluster facilitators' request, CCRC observed and participated in MACS hui and wānanga to collect, analyse, and interpret data for the purpose of promoting the voices and practices of effective, culturally responsive Māori and non-Māori school leaders (Santamaría, 2015). One way CCRC has supported the collaborative learning of MACS principals has been by theoretically grounding MACS principals' efforts towards improving Māori achievement within the educational framework of $\mathrm{Ka}$ Hikitia-Accelerating Success 2013-2017 (Ministry of Education, 2013) (Ka Hikitia). Ka Hikitia identified the following indicators of schools working towards achieving Māori success as Māori in primary and secondary education (Ministry of Education, 2013, p. 36):

- integrate elements of students' identity, language and culture into the teaching and learning curriculum

- use student achievement data to target resources for optimal effect

- provide early, intensive support for those students who are at risk of falling behind

- create productive partnerships with parents, whānau, hapū, iwi, communities and businesses that are focused on educational success

- retain high expectations of students to succeed in education as Māori. 
Although both CCRC and MACS agree that these are important goals for schools to achieve, CCRC and MACS have a shared understanding that to reach these goals first requires, as MACS' vision states, 'a change in the hearts and minds of principals' as well as teachers, whānau, and/or communities. It is important, therefore, to note here that MACS principals are only 2 years into this work. Hence, the focus for principals has been on fostering a shift in their schools' cultures to create environments conducive for these goals being achieved and sustained. As a result, CCRC's evaluative role has targeted the identification of the types of leadership actions necessary for shifting school culture for Māori to succeed as Māori.

\section{CCRC's methodological and theoretical approach to evaluation}

In addition to Ka Hikitia, CCRC researchers also drew on their own strengths and identities in the academe and previous professional practice to engage as partners with MACS. These included the application of two critical methodological practices (kaupapa Māori and critical race theory) and one leadership theoretical framework (applied critical leadership) to inform CCRC's research and involvement with MACS. This section describes these three areas and how CCRC has served MACS as participants, partners, and action researchers.

\section{Kaupapa Māori}

Intended "by Māori, for Māori and with Māori”, kaupapa Māori challenges the privileged status of Western knowledge systems and research methodologies while contesting the exploitative nature of much research that has been undertaken on Māori as subjects being researched (Teariki \& Spoonley, 1992; L.T. Smith, 2012; Walker, Eketone, \& Gibbs, 2006, p. 333). Both CCRC and MACS have worked together to identify leadership strategies for transforming 
mainstream school contexts representative of Western paradigms and historical traditions to render Māori ways of being and thought forms as normative and not the "other". To do so has required the implementation of kaupapa Māori’s six founding principles-tino rangatiratanga, he taonga tuku iho, ako, kia piki ake i ngā raruraru o te kāinga, whānau, and kaupapa (Smith, 1997). Translated within the context of this work, CCRC has aligned its intentions to these founding principles by recognising and prioritising the importance of treaty responsiveness, cultural humility, relational trust, and reciprocity to serve and honour the journeys we have been privileged to be a part of throughout our roles as participants, partners, action researchers, and critical friends (A. P. Santamaría, Webber, \& Santamaría, 2015). Further, this experience may serve as reference point for Māori and non-Māori academics seeking to engage with school leaders to promote Māori success via kaupapa Māori methodology.

In action, CCRC committed to these principles by: integrating MACS principals' feedback into the design of the research instruments to ensure the research was beneficial for all involved; by engaging in pōwhiri, karakia, mihimihi and waiata associated with hui to uphold Māori tikanga; and by embodying the values of whanaungatanga, manaakitanga, kotahitanga, and rangatiratanga. In addition, the principle of àta also informed CCRC's research work as it has served as a guide to the understanding of relationships, negotiating boundaries, and wellbeing in order to create and hold safe space by prioritising reciprocity and parity when engaging with MACS principals (Pohatu, 2004).

\section{Critical race theory}

A second element informing CCRC's partnership with MACS has involved critical race theory (CRT) to address systemic oppression resulting from institutionalised colonisation (Ladson-Billings, 1999; 
Smith, 2006). In Aotearoa New Zealand, systems of ignorance, exploitation, and power often oppress Māori, Pasifika, and other marginalised groups on the basis of ethnicity, culture, mannerisms, and colour (Marable, 1992). In this study, CCRC aimed to support MACS principals' efforts to interrupt traditional ways of thinking about educational leadership by grounding its involvement in critical race theory and social justice inquiry. This enabled CCRC to connect theory to practice or vice versa when contextualising MACS principal leadership practices, while, at the same time, addressing the ongoing Māori struggle for decolonisation that Linda Tuhiwai Smith (2006) has exemplified in her scholarship. This article demonstrates ways in which indigenous "knowing" can be adapted (vs. adopted) by researchers from systemically and/or historically "marginalised" and excluded groups to disrupt dominant paradigms (e.g., scholarly discourse, empirical knowledge, common narratives), adding authentic voices to re-story educational leadership from multiple perspectives where whakaaro Māori is the norm. Moreover, MACS principals' counter-stories, as related to effective school leadership for promoting positive Māori outcomes, were, and continue to be, collected through observation, interviews, surveys, and document analysis as these leaders engage in their practice to foster Māori success as Māori (Solórzano \& Yosso, 2002). These counter-narratives serve to create a record that challenges and interrupts deficit-oriented tales about Māori learners and leadership for Māori (e.g., "the long brown tail", low teacher expectations) for the purpose of adding a "new" perspective and promoting improved leadership practices for indigenous learners in mainstream school settings, while acknowledging these ways of leading are not new in Māori-medium educational contexts.

\section{Applied critical leadership}

Complementing its links to the tenets of kaupapa Māori and 
critical race theory, CCRC's approach for investigating MACS principals' leadership practices also centred on applied critical leadership (ACL), a leadership theory developed by two of CCRC's researchers (Santamaría \& Santamaría, 2012). Grounded in transformative leadership, critical pedagogy, and critical race theory, ACL research explores the ways educational leaders from historically marginalised cultural, racial, ethnic, or linguistic backgrounds are able to use positive aspects of their identity to guide their leadership practice through their ability to identify with, represent the voices of, and act for disenfranchised student populations (Ladson-Billings, 1999; May \& Sleeter, 2010; McLaren, 2003; L. J. Santamaría, 2013; L. J. Santamaría \& Santamaría, 2012; Shields, 2010).

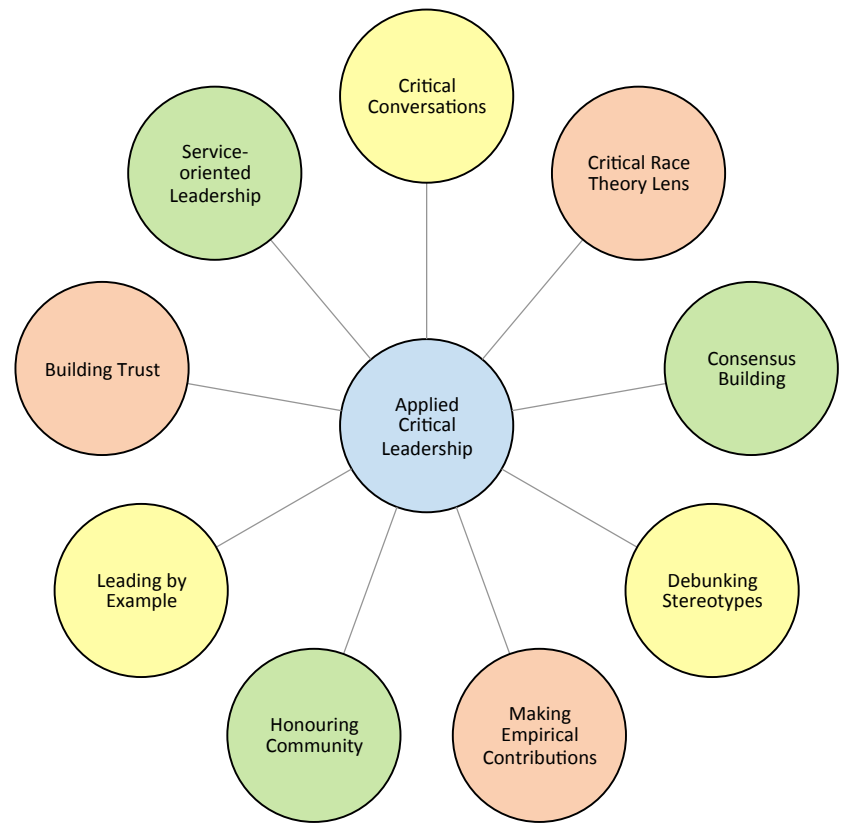

Figure 1. The nine characteristics of applied critical leadership (L. J. Santamaría \& Santamaría, 2012) 
From the onset of the partnership, CCRC did not impose the existing leadership research agenda onto the MACS initiative. On the contrary, through whakawhanaungatanga the MACS' cluster facilitators learned about, and inquired more deeply into, ACL as the partnership was forged. After sharing our leadership research ideologies, MACS began inviting CCRC to present ACL research and findings within MACS cluster hui contexts and at wānanga. As data collection ensued, CCRC began seeing strong links between MACS principals' leadership actions, and ACL characteristics (see Figure 1). Throughout our observations, MACS principals clearly and purposefully engaged in emancipatory leadership practices to address educational issues and challenges using a critical race theory perspective to enact context-specific changes (e.g., choosing to disrupt historical perspectives or practices - teacher expectations, classroom pedagogy, school-home communication — that disadvantaged Māori and other marginalised student populations). These changes were considered critical when having to do with challenges associated with power, domination, access, data interpretation, or achievement (e.g., racial and cultural disparity between classroom teachers and students in need, between students placed in gifted and talented education and those in learning support programs, and between parents serving on school committees) (A. P. Santamaría et al., 2015).

\section{Data collection}

The following questions, driven by CCRC's research, guided the team's critical inquiry into MACS principals' leadership actions to promote Māori success as Māori in mainstream school contexts.

- What does it take in order to be an effective educational leader to improve Māori achievement outcomes?

- What additional skills or training do you need to fine tune your leadership practice, and how/where do you acquire these skills? 
- How does your identity impact your leadership practice?

- What are the most common barriers in your school to improving Māori success?

- How has your collaborative involvement within your MACS regional cluster impacted your leadership practice?

During 2014-2015, the CCRC team collected data by attending, observing and participating in hui in five out of the six regional clusters, two annual wānanga (Kia Aroha College, Auckland in May, 2014; and Ōwae Marae, Taranaki in May, 2015), facilitating 13 individual and seven focus-group interviews, analysing MACS report documents, and by inviting MACS principals to complete two qualitative surveys. One of these surveys centred on principals' leadership practices for improving Māori success $[N=45]$, and the second focused on the outcomes of their collaborative work within regional cluster hui $\left[N=87^{2}\right]$. Each survey yielded a 75 percent principal response rate. Qualitative data analysis was then used to identify key themes aligned to CCRC's guiding research questions and $\mathrm{Ka}$ Hikitia's indicators for fostering Māori success as Māori. All instruments (surveys, interview questions), data (survey results, transcripts), and findings were developed or discussed with MACS' core group of cluster facilitators to ensure accuracy and validity. This occurred before instruments, data, and findings were disseminated to other MACS principals, or used for publication, or a combination of both.

\section{MACS leadership actions}

Data analysis revealed six central themes, each of equal importance, based on the evidence of leadership actions MACS principals are currently engaged in to create optimal school learning environments for

2 There were more hui reflective statement surveys completed than there were MACS principals as principals could complete multiple surveys to provide feedback for each hui attended. 
fostering Māori success as Māori, as aligned to ACL characteristics and the indicators highlighted within Ka Hikitia. Figure 2 represents a graphic representation of the MACS research based on CCRC's current findings.

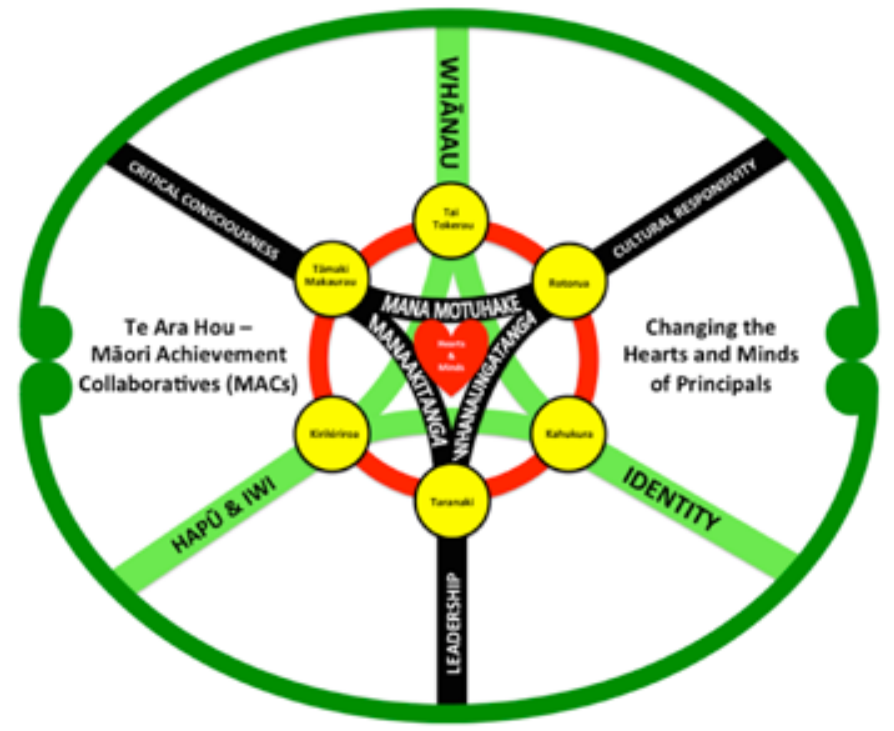

Figure 2. The Cross-Cultural Research Collaborative's graphic representation of Te Ara Hou-Māori Achievement Collaboratives (MACs)

\section{Decolonising leadership}

As stipulated by the Ministry of Education (2013), "Education professionals need to know the best ways to support, teach and engage with Māori students, building on students' inherent capability, cultural assets and existing knowledge. Improving the quality of teaching and leadership is a central action within this focus area" (p. 37). The MACS principals positioned themselves on the front line in leading schools in the process of change, walking alongside their staff in kotahitanga along the journey, and leading from the back as servant leaders to tautoko staff to continue charging ahead. Many 
MACS principals led by example by deliberately role modelling te reo and tikanga (e.g., waiata, karakia, karanga, whaikōrero) throughout their daily interactions with teachers, students, and whānau. One principal stated that "MACS is about leaders stepping up and leading the way" (Kirikiriroa).

For all MACS principals, there has been a basic shared understanding that school leadership involves the provision of direction and exercising influence. This includes the ability to mobilise and work with others to achieve shared goals in order to operationalise Māori success as Māori. For example, a number of the MACS principals stated that, as a result of their participation in MACS, their board of trustees had redeveloped their school charters and annual targets, and many teachers had adapted their appraisal goals, to better reflect the MACS objectives. According to what we have learned from MACS principals thus far (L. J. Santamaría et al., 2014), MACS school leadership actions:

- improve students' learning experiences_- "Students are taking more ownership of their learning journey as they monitor their levels of expectations and share their journey with peers, staff, and whānau" (Rotorua)

- represent and advocate for the voices of those within and beyond the borders of the school (e.g., whānau, hapū, iwi, kaumātua, and community members)_- "Ensuring parents and whānau are listened to and action is taken in relation to what is heard" (Te Tai Tokerau)

- serve as a compass in facilihating learning for leaders and teachers that is inclusive of te ao Māori-"Open honest heart with a willingness to learn, listen, be humble and show reverence to people. Role model your own personal value of Māori and have that expectation of your staff." (Kahukura) 
- respond productively to challenges and opportunities created by integrating te ao Māori within mainstream school contexts- "It is important to be seen to lead and promote te reo and tikanga Māori and discussions around success as Māori." (Hamilton) "Recognition that Māori students need a whānau atmosphere to learn and providing that in the school." (Rotorua)

The spirit of "going there" and leading by example is consistent with findings that suggest that highly localised critical leadership is also taking place in MACS schools (L. J. Santamaría \& Santamaría, 2012). Principals' levels of confidence and efficacy with regard to leading their schools with Māori students and whānau appears to be increasing . According to one principal, MACS "affirms my beliefs, leadership style and allows me to be courageous and serve all my ākonga" (Tāmaki Makaurau).

\section{Leadership whanaungatanga}

From the beginning, MACS has established and maintained effective networks for Māori and non-Māori principals. These networks or clusters have focused on developing tailored approaches to professional learning and development, and school improvement, which have been unique and localised to all participating schools-regardless of their specific challenges, starting points, and identities. MACS clusters engaged in "purposeful peer interaction" (Fullan \& Scott, 2009, p. 153), which works best when the broader values of the school and those of the leaders and teachers mesh, when information and knowledge are shared openly, and when monitoring mechanisms are installed to detect poorly implemented actions and highly effective practices.

All clusters have made substantial progress in reframing the mainstream school experience for Māori students through engendered enthusiastic participant involvement, collaboration, and teamwork. 
MACS' regional cluster design has created much interest, better communication, better understanding, and a substantial leap in hope and belief in the possibility of improved educational achievement for Māori students among school leaders. A key theme that emerged from the data was the importance of "building a positive and collegial school culture ... moving away from working in our separate cells to working more collegially to raise student achievement" (Rotorua).

The data paint a clear picture of the range of new strategies employed to increase Māori student achievement via increased collaboration and interschool networking including "problem solving, sharing practice, sharing understandings, supporting each other... and making sense of our new reality and our future" (Tāmaki Makaurau). Other participants spoke of sharing ideas and success stories, collective leadership and support, and a general willingness by other MACS schools to participate in transformative practices. The data also indicated that the process of involvement in the clusters enabled MACS school leaders and other key staff to become more confident and more effective at meeting Māori students' learning needs. MACS principals spoke of their own professional growth through reciprocal learning opportunities created by engagement with other MACS schools. One non-Māori school leader from an isolated rural school stated "if you are in a school similar to mine don't worry because [in the MACS project] you are not alone" (Hamilton). Another principal stated, “The 'group' helps change the 'group'. Together we can make a difference” (Tāmaki Makarau).

\section{Esteeming Māori identity, knowledge and belief systems}

Māori identity can encompass both traditional Māori concepts that locate identity within whānau, hapū, and iwi, as well as social identity approaches that focus on how students "feel" about being Māori across a range of key contexts. According to the Ministry of 
Education (2013), "Schools and kura that work in partnership with parents, whānau, hapū, and iwi ... can also create learning environments that reinforce the identity, language and culture of Māori students" (p. 41). School is a particularly powerful context for positive Māori identity development. Despite negative stereotypes being prevalent and powerful in the lives of many Māori students, a strong Māori identity may enhance their resilience, providing them with the capacity to prevent negative pressures from interfering with their educational engagement (Webber, 2012).

According to the data, MACS has motivated school leaders to implement activities that enable Māori students to understand and value their Māoriness, including their identity and culture, allowing them to connect with core Māori values. Throughout the clusters, MACS school leaders reported the importance for Māori student expression of identity and cultural growth of activities such as kapa haka, waiata, pepeha, and karakia. Embellishing the school's environment with waharoa, pou and other visual representations of Māoriness, and even so much as changing the school name, have also been implemented to improve the cultural wellbeing of Māori students and their whānau and the overall expression of the school's commitment to affirming and acknowledging Māori identity as the norm and not an exception. As an example, one school has promoted their school's values by designing pou to represent connections to Maniapoto and by renaming classrooms in te reo "to link reflecting growth such as purapura whetū for our new awakening through to tū māia which is about standing confident as seniors" (Kirikiriroa). According to one of the MACS principals, such practices have resulted in a growth in Māori student confidence and capability, which is starting to impact their learning. One principal proposed that schools should ask themselves, "how do Māori students see and hear themselves in your school and ... can they connect with things 
Māori in your school and how visible and audible is Māori in your school?" (Te Tai Tokerau).

MACS schools also have an expectation that staff continue to improve their knowledge and proficiency of te reo Māori by attending te reo language development courses, as well as build their understanding of implementing tikanga in classrooms. One principal is offering PLD to staff to ensure that teachers understand how they are operationalising manakitanga, whanaungatanga and wairuatanga in their classrooms. Many of the MACS schools regularly hold pōwhiri to welcome new staff, parents, and students at the beginning of the school year; begin staff hui with whakataukī, karakia, and waiata (sometimes iwi specific); and focus on a kupu or phrase of the week to encourage staff to improve their reo fluency. In speaking of the progress made in her school, one school leader commented that, "They had a few waiata but no kapa haka, they had no signage, they had nothing really and they've got it all now" (Kirikiriroa).

\section{Whānau/ hapū/ iwi engagement}

Within school settings, MACS principals have fostered consensus building and elicited valuable input from staff, whānau, hapū, iwi, and the local community to better understand what works best for Māori learners. According to the Ministry of Education (2013): "Education professionals must recognise and value the contribution of whānau, hapū and iwi, and build connections with them both inside and outside of school" (p. 41). Through whakawhanaungatanga, principals sought whānau perspective and voice through kōrero (e.g., kanohi ki te kanohi), surveys, hui, informal gatherings, and building links with their local marae in order to integrate students' whakapapa within their schooling experience. Engaging with whānau has enabled principals and their schools to better meet the spiritual, social, physical and educational needs of their tamariki by 
developing Māori-centric graduate profiles; while, at the same time, supporting whānau to improve student learning within the home (Durie, 1998).

For whānau engagement to occur, principals noted the importance of having an "open door" policy to create a welcoming environment for mātua to feel invited to serve as equal partners in their children's education. Principals' active presence at special gatherings and events at their schools, their families' homes or at the local marae has been instrumental in fostering more personal relationships with their students. Ensuring that kaumātua and whānau not only felt welcome within the school, but were invited to join key representative groups and committees, including boards of trustees, to inform school practices or even provide PLD to improve teachers' reo and tikanga was another common Treaty-based strategy employed by MACS principals. Over the course of the 2 years of this study, data suggests that greater numbers of principals across the MACS clusters have moved from establishing the need for whānau engagement (a key theme in 2014) to implementing community-informed practices that establish strong whānau partnerships for supporting student learning (a key theme in 2015).

MACS principals have also begun to foster strong partnerships with hapū and iwi to identify ways of improving how their schools provide education for their tamariki. Some principals did this by ensuring tangata whenua sat on their boards of trustees, or by consistently consulting with hapū and iwi to inform school decision-making, or a combination of both. Some principals also provided a designated office space for hapu or iwi within the school and invited education representatives or kaumātua to provide teachers with PLD to make curriculum more relevant to their tamariki. Establishing productive hapu and iwi partnerships is one of MACS priorities for 2016 and is the central theme for the 2016 annual wānanga in Rotorua. 


\section{Culturally responsive pedagogy}

There is a rigorous body of research-based literature on culturally responsive pedagogy that is germane to Aotearoa New Zealand where the majority of Mãori and Pasifika learners are being taught in mainstream schools where they are the minority (Bishop \& Berryman, 2006; Bishop et al., 2009; Durie, 2001; Macfarlane, Glynn, Cavanagh, \& Bateman, 2007). This literature is unique to other research on culturally responsive pedagogy because, in Aotearoa, there are Māori educational contexts where whakaaro Māori are normalised (e.g., kōhanga reo, kura, wānanga). Within these contexts, teaching is not "responsive", but rather appropriate, and it represents the norm of what teachers and leaders do. This is the direction the MACS principals are taking.

Drawing from the work of Bishop et al. (2009), there are clear links between the kaupapa of Te Kotahitanga at the secondary level and MACS at the primary and intermediate levels. For one, MACS principals have focused on purposefully rejecting deficit theorising as an explanation of Māori student achievement in order to "value, engage with, respect and embrace students' history, who they are, their struggle and their victories, as well as cultural practices" (Tāmaki Makaurau). Principals and schools have embraced mana motuhake by "helping students to understand and value their Māoriness-identity, culture and allowing them to connect with our core values and living these values as Māori” (Tāmaki Makaurau); by promoting whakapiringitanga by designing and creating "Māori art, pou for the school entrance, artwork for school gardens, and kapa haka uniforms" (Hamilton); and by integrating ako via noho marae, wānanga, and culturally responsive pedagogy to build and strengthen teacher-student and student-student reciprocal relationships (e.g., tuakana-teina strategies).

There has also been a major emphasis on bringing in "local iwi to inquire into our history to develop a more culturally responsive and 
localised school curriculum" (Tāmaki Makaurau), as well as "asking iwi to develop curriculum with local stories and tribal knowledge" (Te Tai Tokerau). There was multiple mention of drawing knowledge and history from whānau as a source of legitimate knowledge to advance the National Standards curriculum and "improve whānau engagement in learning" (Kirikiriroa). One principal stated, "As a school we have really learnt about our place, the history of our place ... and the children have really started to get into and understand who they are, where they are from and the history of our area" (Kahukura). MACS leaders continue to incorporate knowledge from Māori researchers and local role models from which to draw and develop their curriculum by "identify[ing] and invit[ing] key skilled community members to share experiences" (Rotorua). Most recently, MACS clusters have begun investigating A Critical Guide to Māori and Pākehā Histories of Aotearoa as a curriculum programme resource for mainstream and Māori medium pathways (Hanly, 2015).

\section{Critical consciousness}

Freire (1970) promulgated the notion of growing a critical mass of progressive like-minded thinkers to push back on injustices faced by the systemically underserved, where decolonialism is the aspiration of the group. Here in Aotearoa, Smith (2003) and others, including MACS principals, are engaged in similar work with a Māori-successas-Māori focus to transform education, schooling, and leadership. According to the data, MACS is, as one school leader put it, "an excellent vehicle for starting conversations and exploring the possibilities" (Kahukura). MACS provides safe spaces for school leaders to come together to be inspired by others, to network, to hear about and share what works in other schools, and to support each other. As one school leader notes of MACS, "I have gained inspiration, knowledge, mentors and connections. Excellent!" (Hamilton). 
MACS' vision of "changing hearts and minds" is an act of critical conscientisation - one that MACS principals need to negotiate either internally, through their own journey of serving Māori communities, or externally, through shifting current systems of practice positioned in mainstream school settings to foster Māori success as Māori. MACS principals noted the challenges with negotiating these two worlds, but expressed strong conviction to confront the barriers before them and courageously lead their schools for change. For Māori principals, the kaupapa of MACS has nourished the wairua that had, for so long, been pushed to the side by Western influences (competition, autonomy, academic achievement results). For nonMāori principals, this has been an opportunity to embrace their own identities (e.g., Pākehā, Samoan, Cook Island), take on a critical race theory lens, awhi their indigenous sisters and brothers, and passionately lead their communities in dispelling deficit-based stereotypes towards Māori, Pasifika, and other marginalised student populations.

\section{Conclusion}

The intent of this article was to highlight and promote the effective, culturally appropriate leadership practices of Te Ara Hou-Māori Achievement Collaboratives. Throughout the analysis of data collected during CCRC's collaborative partnership as action researchers, clear theory-to-practice connections were made between MACS leadership actions and kaupapa Māori, critical race theory, Ka Hikitia and applied critical leadership-the methodological and theoretical frameworks underpinning this work (See Table 1).

Table 1 (facing). Contextualising this study's thematic analysis of MACs Leadership Actions within Ka Hikitia, kaupapa Māori (KM), critical race theory (CRT) and applied critical leadership (ACL) 


\begin{tabular}{|c|c|c|c|}
\hline Ka Hikitia elements & Thematic analysis & MACs Leadership Actions & $\begin{array}{l}\text { Methodological and } \\
\text { theoretical links }\end{array}$ \\
\hline $\begin{array}{l}\text { "Knowing the best } \\
\text { ways to support, } \\
\text { teach and engage } \\
\text { with Māori students" } \\
\text { - "Improving the } \\
\text { quality of teaching } \\
\text { and leadership" } \\
\text { (p. 37) }\end{array}$ & $\begin{array}{l}\text { Decolonising } \\
\text { leadership }\end{array}$ & 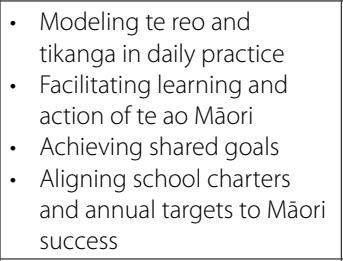 & $\begin{array}{l}\text { KM: Prioritising te reo and te } \\
\text { ao Māori } \\
\text { ACL: Leading by example; } \\
\text { Consensus building; Service- } \\
\text { oriented leadership }\end{array}$ \\
\hline $\begin{array}{l}\text { "Increasing } \\
\text { opportunities to } \\
\text { better share good } \\
\text { practice so that it } \\
\text { becomes common } \\
\text { practice" (p. 40) }\end{array}$ & $\begin{array}{l}\text { Leadership } \\
\text { Whanaungatanga }\end{array}$ & $\begin{array}{l}\text { Formation of clusters to } \\
\text { promote inter-school } \\
\text { collegiality } \\
\text { - Intra-school networks } \\
\text { that foster positive, safe } \\
\text { spaces for personal and } \\
\text { professional growth }\end{array}$ & $\begin{array}{l}\text { KM: Kanohi ki te kanohi, } \\
\text { whakawhanaungatanga } \\
\text { ACL: Building trust }\end{array}$ \\
\hline $\begin{array}{l}\text { "Creating learning } \\
\text { environments } \\
\text { that reinforce the } \\
\text { identity, language } \\
\text { and culture of Māori } \\
\text { students" (p. 41) }\end{array}$ & $\begin{array}{l}\text { Esteeming Māori } \\
\text { identity, knowledge } \\
\text { and belief systems }\end{array}$ & $\begin{array}{l}\text { - Infusing te reo and tikanga } \\
\text { in daily school practice } \\
\text { - Developing a bicultural } \\
\text { school landscape } \\
\text { - High expectations for staff } \\
\text { to develop their knowledge } \\
\text { and practice of te reo and } \\
\text { tikanga } \\
\text { - Positioning practice within } \\
\text { te ao Māori }\end{array}$ & $\begin{array}{l}\text { KM: Prioritising te reo, tikanga, } \\
\text { and te ao Mãori; Treaty } \\
\text { responsiveness } \\
\text { ACL: CRT lens; Debunking } \\
\text { stereotypes }\end{array}$ \\
\hline $\begin{array}{l}\text { "Creating productive } \\
\text { partnerships } \\
\text { with parents, } \\
\text { whanau, hapū, iwi, } \\
\text { communities and } \\
\text { businesses that } \\
\text { are focused on } \\
\text { educational success" } \\
\text { (p. } 36)\end{array}$ & $\begin{array}{l}\text { Whānau / hapū/ iwi } \\
\text { engagement }\end{array}$ & $\begin{array}{l}\text { - Kanohi ki te kanohi } \\
\text { interactions with whanau } \\
\text { - Open door policy } \\
\text { - } \text { Active presence at special } \\
\text { events } \\
\text { - } \text { Activating voices of } \\
\text { kaumātua and whanau } \\
\text { - Establishing committee } \\
\text { roles for tangata whenua } \\
\text { - Developing Māori-centric } \\
\text { graduate profiles } \\
\end{array}$ & $\begin{array}{l}\text { KM: tino rangatiratanga, } \\
\text { Kanohi ki te kanohi, } \\
\text { whakawhanaungatanga } \\
\text { ACL: Honouring community; } \\
\text { consensus building }\end{array}$ \\
\hline \multirow[t]{2}{*}{$\begin{array}{l}\text { "Integrating } \\
\text { elements of students' } \\
\text { identity, language } \\
\text { and culture into the } \\
\text { curriculum teaching } \\
\text { and learning" (p. 36) }\end{array}$} & $\begin{array}{l}\text { Culturally } \\
\text { responsive } \\
\text { pedagogy } \\
\end{array}$ & $\begin{array}{l}\text { - Coordinating noho marae } \\
\text { and wānanga } \\
\text { - Bridging National Standards } \\
\text { and te ao Māori } \\
\text { - Connecting local Māori } \\
\text { histories }\end{array}$ & $\begin{array}{l}\text { KM: Mana motuhake; } \\
\text { whakapiringitanga; ako } \\
\text { ACL: Making empirical } \\
\text { contributions; CRT lens; } \\
\text { Debunking stereotypes }\end{array}$ \\
\hline & $\begin{array}{l}\text { Critical } \\
\text { consciousness }\end{array}$ & $\begin{array}{l}\text { - Establishing critical mass } \\
\text { of effective leadership for } \\
\text { Māori success as Māori } \\
\text { - } \quad \text { Changing hearts and minds }\end{array}$ & $\begin{array}{l}\text { KM: Social justice } \\
\text { ACL: Social justice and } \\
\text { equity; CRT lens; Critical } \\
\text { conversations }\end{array}$ \\
\hline
\end{tabular}


In summary, CCRC's evaluative analysis of MACS' mahi in mainstream primary and intermediate school settings yielded six central themes identifying key leadership actions, which demonstrate MACS principals' progress towards meeting the goals discussed earlier in this article. In positioning these actions within a Ministry of Education lens, strong links can be drawn to one of the current frameworks for supporting education success for Māori students as Māori: Ka Hikitia-Accelerating Success 2013-2017 (Ministry of Education, 2013). As stated earlier, current MACS' mahi is focused on changing hearts and minds through shifting school cultures to create learning environments wherein Māori can succeed as Māori. As such, CCRC has not focused on measuring MACS schools' student achievement outcomes in literacy and maths, but rather the actions MACS principals are taking to create the necessary environments for such outcomes to materialise. This focus on leadership practice is critical for other school leaders and educational bodies to understand as it shifts the purpose of educational reform from an end product back to the original source education is intended to serve-the students themselves, their livelihood, aspirations, and identity.

Furthermore, MACS principals' leadership data serve as counter-stories to provide exemplars to demonstrate the potential when using kaupapa Māori, applied critical leadership, and other indigenous, culturally responsive forms of knowledge to shift mainstream systems of practice toward a more bicultural, Treaty-responsive ideology of schooling (Solórzano \& Yosso, 2002). As demonstrated here, it is critical that school principals understand their current positioning within their schools (e.g., cultural, political, ethical) as well as the positioning they need to initiate a shift in the school cultures they lead. Embodying kaupapa Māori, te ao Māori, and other indigenous ways of being is not to be taken lightly, nor is it to be taken for granted. It is to be considered a taonga and should be enacted with a 
sense of purpose and social justice.

E ngā tumuaki o te motu, e ngā pou o te ako, e ngā pūtake o te mārama, e ngā mana o te iwi, tēnei ngā mihi atu ki a koutou.

Anei te kāhui rangahau e whāriki atu nei i mua i te aroaro o te hunga mātauranga.

Hopukina mai, wānangatia, kōrerotia, me whakamahingia.

Nā reira, huri noa i te motu, tēna koutou katoa.

\section{Glossary}

ako culturally preferred pedagogy

ākonga learners

ao to dawn, bright, world

Aotearoa New Zealand

àta carefully, deliberately

hapū kinship group, subtribe

he taonga tuku iho cultural aspirations

iwi extended kinship group, tribe-often refers to a large group of people descended from a common ancestor and associated with a distinct territory

hui meeting

Ka Hikitia to step up, to lift up or to lengthen one's stride

Kahukura Christchurch

kanohi ki te kanohi face-to-face

kapa haka Māori performing group

karakia prayer

karanga formal call, ceremonial call, welcome call

kaumātua elderly Māori with status

kaupapa purpose, collective philosophy

Kia Aroha College a secondary school located in Auckland

kia piki ake i ngā raruraru o te kāinga socio-economic mediation Kirikiriroa Hamilton 
kōhanga reo Māori language preschool

kotahitanga common vision, unity, solidarity

kuia elderly woman, grandmother, female elder

kupu word

kura school

mahi work

mana motuhake caring for the performance of students

manaakitanga hospitality

marae local meeting house

mātauranga Māori Māori ways of knowing

mātua parents

mihimihi to greet, pay tribute, thank

Ngāpuhi Northland tribe in Aotearoa/New Zealand

Ngāti Whakaue a Māori iwi of New Zealand currently living in the

Rotorua district and descends from the Arawa waka

Ōwae Marae the central marae of Te Āti Awa (a Māori iwi with

traditional bases in the Taranaki and Wellington regions of New

Zealand) in Waitara

pepeha tribal saying, tribal motto, set form of words

pou post, pole, pillar

pōwhiri to welcome, invite

purapura whetū a tukutuku (lattice-work) pattern that represents

the stars and the great numbers of people of a nation

rangatiratanga self-determination, autonomy

reo Māori language

Tāmaki Makaurau Auckland

tamariki children

tangata whenua people of the land, local people, indigenous people tautoko to support

te the

Te Akatea New Zealand Māori Principals’ Association 


\section{Te Ara Hou The New Pathway}

Te Tai Tokerau Whangarei

Te whare tapa whā a Māori health model (Durie, 1998)

tikanga customs

tino rangatiratanga self-determination, sovereignty, autonomy

tuakana-teina older/younger, more/less experienced

tū māia to be brave, to stand strong

waharoa main entranceway

waiata to sing, song

wairua spirit

wairuatanga spirituality

wānanga extended, sometimes overnight, educational seminars or gatherings

whaikōrero to make a formal speech

whakaaro thought, understanding

whānau extended family structure

whakapiringitanga the creation of safe, secure, well-managed learning space that incorporates pedagogical knowledge and imagination whakataukī proverb

whakawhanaungatanga the building of relationships

whanaungatanga relationships, kinship, sense of family connection

\section{References}

Alton-Lee, A. (2003). Quality teaching for diverse students in schooling:

Best evidence synthesis. Wellington: Ministry of Education.

Baker, M., Pipi, K., \& Cassidy, T. (2015). Kaupapa Māori action research in a Whānau Ora collective: An exemplar of Māori evaluative practice and the findings. Evaluation Matters_He Take Tō Te Aromatawai, 1, 113-136. http://dx.doi.org/10.18296/em.0006

Bishop, R., Berryman, M., Cavanagh, T., \& Teddy, L. (2009). Te

kotahitanga: Addressing educational disparities facing Māori students in 
New Zealand. Teaching and Teacher Education, 25(5), 734-742. http://dx.doi.org/10.1016/j.tate.2009.01.009

Bishop, R., \& Berryman, M. (2006). Culture speaks: Cultural relationships and classroom learning. Wellington: Huia.

Durie, M. (1998). Whaiora: Māori health development. Auckland: Oxford University Press.

Durie, M. (2001). A framework for considering Mãori educational advancement. Paper presented at the Hui Taumata (1), Turangi and Taupo, New Zealand.

Freire, P. (1970). Cultural action and conscientization. Harvard Educational Review, 40(3), 452-477. http://dx.doi.org/10.17763/ haer.40.3.h76250x720j43175

Fullan, M. \& Scott, G. (2009). Turnaround leadership for higher education. San Francisco, CA: Jossey-Bass.

Hanly, T. (2015). A critical guide to Mãori and Päkehä histories of Aotearoa. Retrieved from criticalhistories.nz

Ladson-Billings, G. (1999). Preparing teachers for diverse student populations: A critical race theory perspective. Review of Research in Education, 24, 211-247. http://dx.doi.org/10.2307/1167271

Macfarlane, A., Glynn, T., Cavanagh, T., \& Bateman, S. (2007). Creating culturally-safe schools for Māori students. Australian Journal of Indigenous Education, 36, 69-76.

Marable, M. (1992). Black America. Westfield, NJ: Open Media.

May, S., \& Sleeter, C. E. (Eds.). (2010). Critical multiculturalism: Theory and praxis. New York, NY: Routledge.

McLaren, P. (2003). Life in schools: An introduction to critical pedagogy in the foundations of education (4th ed). Albany, NY: Allyn and Bacon.

Ministry of Education. (2013). Ka hikitia-Accelerating success 2013-2017. Wellington, New Zealand: Ministry of Education.

Pearson, H., Witana, P., Ritai, D., Lander, M., McQuillan-Mains, R., Naera, 
J., \& Newman, P. (2014, August). Te Ara Hou-Māori Achievement Collaboratives (MACS) report on progress and achievement to date. Auckland: Te Ara Hou-Māori Achievement Collaboratives.

Pohatu, T. (2004). Ata: Growing respectful relationships. Retrieved from http://www.kaupapamāori.com/assets/ata.pdf

Santamaría, A. P., Webber, M., \& Santamaría, L. J. (2015). Effective school leadership for Māori achievement: Building capacity through Indigenous, national and international cross-cultural collaboration. In N. D. Erbe \& A. H. Normore (Eds.), Cross-cultural collaboration and leadership in modern organizations (pp. 99-119). Hershey, Pennsylvania: IGI Global. http://dx.doi.org/10.4018/978-1-4666-8376-1.ch007

Santamaría, L. J. (2013) Critical change for the greater good: Multicultural dimensions of educational leadership toward social justice and educational equity. Education Administration Quarterly, 50(3), 347-391. http://dx.doi.org/10.1177/0013161X13505287

Santamaría, L. J. (2015). Culturally responsive leadership in cross-cultural international contexts. In N. D. Erbe \& A. H. Normore (Eds.), Crosscultural collaboration and leadership in modern organizations (pp. 120-139). Hershey, PA: IGI Global. http://dx.doi.org/10.4018/978-1-4666-8376-1. ch008

Santamaría, L. J., \& Santamaría, A. P. (2012). Applied critical leadership: Choosing change. New York, NY: Routledge Books.

Santamaría, L. J., Santamaría, A. P., Pearson, H., \& Webber, M. (2015). Indigenous school leadership in New Zealand: Cultural responsivity for diverse learners in urban schools. In M. Khalifa, C. Grant, \& N. Witherspoon Arnold (Eds.), Handbook of urban educational leadership (pp. 532-545). Lanham, Maryland: Rowman \& Littlefield Publishers.

Santamaría, L. J., Santamaría, A. P., Webber, M., \& Pearson, H. (2014). Indigenous urban school leadership: A critical cross-cultural comparative analysis of educational leaders in New Zealand and the United States. Canadian and International Education/Education canadienne et international, 43(1), Article 5. 
Shields, C. M. (2010). Transformative leadership: Working toward equity in diverse contexts. Education Administration Quarterly, 46(4), 558-589. http://dx.doi.org/10.1177/0013161X10375609

Smith, G. H. (1997). The development of kaupapa Māori: Theory and praxis. Unpublished doctoral thesis, University of Auckland.

Smith, G. H. (2003, October). Indigenous struggle for the transformation of education and schooling. Keynote address to the Alaskan Federation of Natives Convention, Anchorage, AK.

Smith, L. T. (2006). Choosing the margins: The role of research in indigenous struggles for social justice. In N. K. Denzin \& M. D. Giardina (Eds.), Qualitative inquiry and the conservative challenge (pp. 151-174). Walnut Creek, CA: Left Coast Press.

Smith, L. T. (2012). Decolonizing methodologies: Research and indigenous peoples. London, UK: Zed Books.

Solórzano, D. G., \& Yosso, T. J. (2002). Critical race methodology:

Counter-storytelling as an analytical framework for educational research. Qualitative Inquiry, 8(1), 23-44. http://dx.doi.org/10.1177/107780040200800103

Teariki, C., \& Spoonley, P. (1992). The politics and process of research for Mãori. Palmerston North: Massey University Press.

Walker, S., Eketone, A., \& Gibbs, A. (2006). An exploration of kaupapa Māori research, its principles, processes and applications. International Journal of Social Research Methodology, 9(4), 331-344. http://dx.doi.org/10.1080/13645570600916049

Webber, M. (2012). Identity matters: Racial-ethnic identity and Māori students. Set: Research Information for Teachers, 2, 20-27.

Wylie, C. (2009). Tomorrow's Schools after 20 years: Can a system of selfmanaging schools live up to its initial aims? New Zealand Annual Review of Education, 19, 5-29. 


\section{The authors}

Andrés P. Santamaría: Auckland University of Technology,

New Zealand

Email: asantama@aut.ac.nz

Melinda Webber, Lorri J. Santamaría, Lincoln I. Dam,

Sharona Jayavant: The University of Auckland, New Zealand 